\title{
COVID-19: challenges and opportunities in Indonesia health sector
}

\author{
Barokah Sri Utami ${ }^{1^{*}}$, and Pradip Iramdhan Aliyansah ${ }^{2}$ \\ ${ }^{1}$ Former President Director of PT. Phapros Tbk., Indonesia \\ ${ }^{2}$ Community on Pharmaceutical Industry Practices chapter Central Java, Indonesia
}

\begin{abstract}
Covid-19 pandemic has gripped over than 210 countries in the world, not to mention Indonesia, and will reshape the current society in every aspect. Historically, the current pandemic is not the first one which happen in the world. Spanish flu's outbreak in 1918 had killed more than 50 millions worldwide. However, there would be a different response on environment, lifestyle, society, and technology between the past and the current pandemic. The urgent requires for coping pandemic challenges the humanity in terms of effort regarding to vaccine, medicine, health supplement, medical device development and innovation. Those efforts are purposed not only for the medication, but also the for the prevention, specifically for the initial diagnostic. Blessed with a massive biodiversity, Indonesian society wisely utilize their local wisdom by consuming the herbal potion, to increase their immunity system as their first line response. Besides the prevention of Covid-19 protocol, Indonesia actively elaborates with another country to discover the vaccine and other beneficial aspects. The establishment of Covid-19 pandemic mitigation and national economic recovery, by the means of presidential regulation (Perpres) No. 82/2020, signals the synergy effort of economic recovery and health programme. In addition, to promote the scientific manner of society, government issues the presidential instruction (Inpres) No. 06/2020. Those regulations are believed will boost the new normal adaptation process.
\end{abstract}

\section{Introduction}

The spread of the novel coronavirus, SARS CoV-2 was officially defined as a pandemic by the World Health Organization (WHO) on March $11^{\text {th }}, 2020$ due to its sudden emergence and expansion around the world. The virus, now called Covid-19, has spread over and contracted to more than 210 countries [1]. Historically, the current pandemic was not the first one which affecting the whole world. The last pandemic with huge deaths, the 1918 Spanish flu, is the avian-borne flu that resulted the death of 50 million people worldwide because the knowledge of virus and technology were not as advance as today. However, what proven to be effective was the social distancing [2]. The lesson learned from the past have given the humanity to combat better in the current pandemic of Covid-19, but there are differences in method and treatment of the virus as many factors such as lifestyle,

\footnotetext{
${ }^{*}$ Corresponding author : emmy.bsriutami@gmail.com
} 
technology and society affect the approach method. Covid-19 have contracted around 19,3 million of people and caused at least 704.000 deaths all across the world. As in Indonesia, there are 115.000 of positive cases and more than 5.000 people dead because of the virus [1]. As the number of cases keep going up, Indonesia's rank for coronavirus testing rate was considered one of the worst among world. The world's fourth-most populous country of 270 million performed better than only Ethiopia, Nigeria, and Bangladesh [3]. Up until now, the world still fighting against the pandemic and currently the absence of definitive treatment for this novel infectious disease is worrying for many countries.

Indonesia as one of the most populated country also seriously affected by the current pandemic. Particularly in health sector, before the outbreak of the pandemic, Indonesian Ministry of Trade predicted the Indonesia Pharmaceutical National market value reaching 450 trillion rupiahs in 2025 and became the $15^{\text {th }}$ world rank. To compare with, in 2018, pharmacy market had value of 80 trillion rupiahs and in $20^{\text {th }}$ world rank [4].

Indonesia, as one of the country which commit to implement sustainable development goals (SDGs), aiming to reach that goals supported with Indonesian Minister of Health programme which are the decreases of TBC diseases prevalence, the decrease number of stunting children, and the evenly distributed of vaccine. These programmes are stated in middle term national development program for 2020-2024, focused on preventive disease. Covid-19 clearly causes massive impact to all of nations, including Indonesia, and every nations is struggling with it. If the pandemic could not be solved in a short time, Indonesia settled target for either in health or economy sector is threatened as has been explained as above. Fighting against the pandemic is not an easy tasks as the world currently unify to fight it. However, the pandemic had caused negative impact for Indonesia. For example, the increases rate of unemployment and the restriction measures imposed by government to hold the rapid spread of Covid-19 led consumer to stay at home made Indonesia's annual inflation rate dropped to $1,54 \%$ in July 2020 [5], the lowest since 2000.

\section{The Challenges and the Opportunities Identify the Problem, Root Causes and Find the Solution}

\subsection{Covid-19 reshapes health sector business model}

Even though in midst of economy crisis threat, surprisingly Indonesian market for consumer goods grew well when the first case was confirmed. Generally the world experience negative growth after Covid-19 outbreak happened [6]. In figure 1, for example in pharma and cooking seasoning product, the growth were significantly higher than global growth of either pre Covid-19 or after Covid-19 outbreak with $48 \%$ and $44 \%$ respectively. In figure 3 moreover, hygiene-related goods like vitamin, detergent and toilet soap were reported to experience the most high level growth among 10 top non-food categories[6]. It might indicates there were changes in consumption habit of Indonesian society during the pandemic. The shifting behaviour might aligns with society tend to enhance their immunity system, as self medication and prevention effort towards viruses. Furthermore, government restriction regarding mobility gives impetus to home-based activity in society such as self-growing food and home-made food business. 


\section{AS INDONESIA CONFIRMED ITS FIRST CASE, COOKING AND PHARMA PRODUCTS INCREASED MOST IN GROWTH}

$\%$ Value Growth vs YA | Total Key Accounts | 111 CAT by Sector

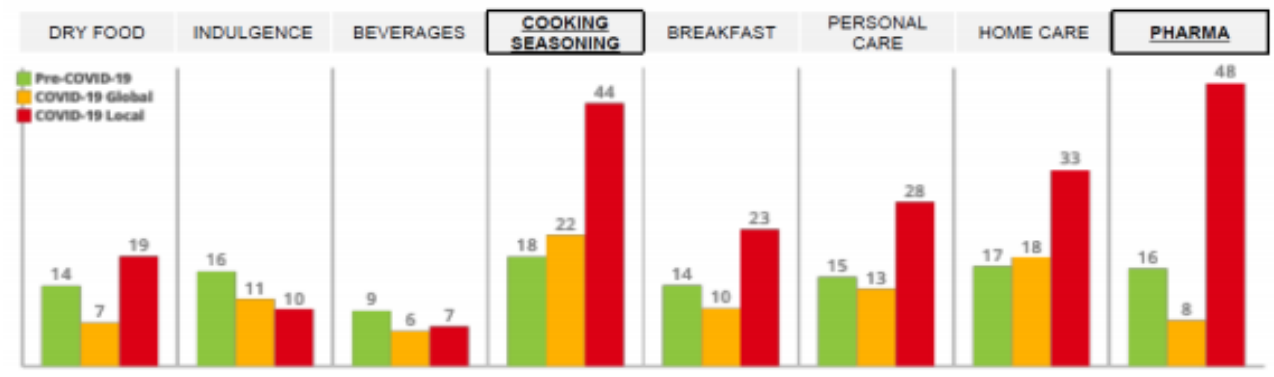

Fig. 1. Growth value diagram of consumer goods as globally and locally (Indonesia), before and after covid-19 outbreak

\section{HYGIENE-RELATED PRODUCTS AND VITAMINS GREW THE MOST AT COVID-19 LOCAL PHASE IN TOP 10 NON-FOOD CATEGORIES}

$\%$ Value Growth vs YA | Total Key Accounts | Top 10 Non-Food Categories

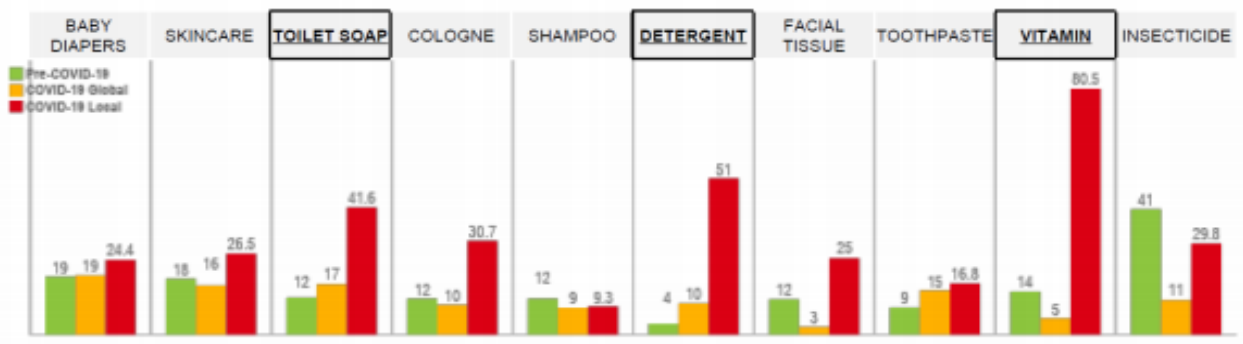

Fig. 2. Growth value diagram of top 10 non-food categories in hygiene related products globally and locally (Indonesia), before and after covid-19 outbreak

Another noticeable growth particularly in pharmacy product, which hand sanitizer sells massively rose [6] while medicinal product, especially the one which medicinal prescription required, fell. For example, travel relief medicine in Indonesia fell to around $25 \%$ of market sells. In American pharmaceutical market, although there was significant growth in total prescriptions during the first quarter, which peaked the week ending March 27, 2020, then it fell below expected annual averages. [7].

Ironically, while the world had suffered through other past pandemics caused by virus, yet no nations are ready to face the current pandemic. Initially surfaced in Wuhan, China, in the end of 2019, WHO announced Covid-19 outbreak as pandemic several times later in 2020 , including in Indonesia. In the health sector, the major challenges in between are the capability of screening for viruses, at least 1:1000 population ratio. Currently, Indonesia is only able to reach 0,4:1000 population ratio [8], hence extra efforts are needed. Several factors which might become root causes are the limited testing diagnostic device to understand the prevalence rate until recovery rate which led to inaccuracy prediction and limited number of laboratory and hospital which qualify for Covid-19 samples testing as 
Bio Safety Level III facility is required. Those factors led to the incapability of health service to plan and carry out the scheme to combat the corona viruses.

On other hand, the restriction of activity such as social distancing results in a huge gap between demand and supply and the arising of irresponsible group of people who exploit the situation. Indonesia's heterogeneous age demographics results in difference understanding of people regard to the health knowledge. Consequently, they are become vulnerable to the misinformation. For example if there is a certain group of people who claim the Covid-19 cure yet the medicine is still scientifically and clinically unproven might led devastating effect on society. The situation turned from bad to worse if the particular group is supported by some public figures. Therefore as a vital role in public information role, public figures should only giving the truth and prevent the information to turn disarray. In addition, the protection for the people from the roles of National Food and Drug Agency of Indonesia (BPOM), Ministry of Health and other government agency and academic from university are severely required.

\subsection{The race attempting to find a Covid-19 vaccine and other way to boost human immune system}

Until this day, there is still no definitive cure for Covid-19 either it is chemical medicine-based, biological medicine-based, herbal medicine-based and vaccine. The latest research on Covid-19 vaccine is currently undergoing the clinical phase III test, which the vaccine is a results of Bio Farma, a state owned company of Indonesia and Sinovac from China collaboration. The vaccine is estimated to be ready for pre-clinical trial in early 2021 $[9,10]$. Having certified by WHO to export vaccine, Bio Farma has exported to more than 140 countries and has established for more than 130 years.As a result, Bio Farma have appointed by Indonesian government to conduct clinical phase III test. If the test resulting in a success, Bio Farma has a great opportunity to supply Covid-19 vaccine throughout the world. Meanwhile, for a longer-term, self-sufficient strategy, a national consortium under the Research and Technology Ministry is working on developing its own vaccine, led by the Eijkman Institute, a well-established Molecular Biology Laboratory. The vaccine itself will be named after Indonesia's flag colors, Merah Putih, or red and white [11]. In addition to Bio Farma, there is also a private pharmaceutical company from Indonesia which develops Covid-19 vaccine as well. However, the development of vaccine is not only done by Indonesia and China but also other countries. In Russia, the Covid-19 vaccine is reported to be ready in November 2020 [12]. Therefore, more and more countries are racing to become the first nation to develop and establish the vaccine, and its discovery turns to be crucial for all the world.

While waiting for the Covid-19 vaccine to be ready, Indonesian people have initiated and helped themselves by consuming herbal medicine, "Jamu", to boost immunity system. However, the medicine are intended only for preventive purposes, not for curing purposes to novel coronavirus. The biodiversty of plants in Indonesia make its people easily obtain the herbal which few of them are empirically proven to increase body immune. Herbal medicine is categorized by National Food and Drug Agency of Indonesia (BPOM) to traditional herbal medicine or "Jamu", standardized herbal medicine and phytopharmaka which the latter is defined as scientifically and clinically proven herbal. The status pushes some industries to conduct clinically research in order to raise the doctor acceptance to herbal medicine. Furthermore it could be given as complementary therapy. Besides, to support the medicine usage of Covid-19, National Food and Drug Agency of Indonesia (BPOM) has issued a relaxation for certain regulation involved with health supplement and food which are dominated by multivitamin product and low-risk product since it is urgently needed for society. In addition, BPOM issues emergency use authorization for medicine 
used in Covid-19 treatment such as dexamethasone, rendemsivir, chloroquin and hydrxychloroquin as chemical product example and interferon as biology product example. In medical device section, marketing authorization given by Ministry of Health for medical device included in the regulation relaxation as well. Personal protection equipment such as mask, diagnostic kit, PCR swab test kit, which are initially imported now Indonesia could produce it locally not to mention ventilator which are developed and produced as the result of academic, business, community, and government (ABCG) collaborative scheme.

Nowadays, many diseases not only related to the infectious disease, metabolise diseases but also immunity-related diseases.such as caused by virus. As the virus is a self-limiting disease which heavily dependent on host's immunity, nevertheless the definitive medicine and vaccine should be found as soon as possible. Therefore the future pandemic would be prevented. The understanding of epidemiology, virology, molecular biology and related future diseases sciences would become a vital knowledge needed based on scientific and application approach.

The change of behaviour to become more aware to the prevention of Covid-19 spread pushes the remote transaction business which avoids direct contact. The development resulting in the needs of digital health care such as telemedicine and digital health consultation. The outbreak of the pandemic acts as an accelerator for the application of low touch economy and also big data scientific and analytic which would be useful to help the business or to fight the pandemic. The Indonesian governments are aware of this issue so the government sets up large-scale social restriction rather than lockdown policy in a bid to prevent further business collapse and improve the purchasing ability of society.

However it is inescapable that the demand of investment either locally or globally gradually stepping down which is indicated by the decrease of IHSG (composite stock index in Indonesia) [13]. The report showed that the drop of stock price signs there might be an economic recession. However, the investor still interested in the pharmaceutical company's stock of Indonesia which the growth of stock price is generally higher than other business company. The raising price of pharmaceutical company in stock market began as the state owned pharmaceutical company as the ultimate share holder is appointed to take the responsibility of Covid-19 vaccine production. Therefore, the investors are quite anticipated to see that the Covid-19 vaccine clinical test meet a success.

\subsection{Policies by the Indonesian government related to coronavirus outbreak}

Initially, Indonesian Government deployed Covid-19 Task Force focused on tackling the coronavirus spread. However, with the number of the Covid-19 cases keeps growing in the country, Indonesia faces a real recession threat in which has responded by the country President, Joko Widodo, by concocted a new committee tasked with dual aims of maintaining economic growth and curbing the novel coronavirus spread [14] stipulated in Article 19 of Presidential regulation (Prepres) No. 82/2020, shifting Covid-19 Task Force focus to Covid-19 pandemic mitigation and national economic recovery [15]. The committee, lead by Indonesian chief Ministry of State-Owned Enterprises and Coordinating Ministry for Economic Affairs which aimed to balancing health and economy matters in coping with the deadly coronavirus pandemic. The task force describes the national government effort taking role to help Indonesia from the pandemic. The government strategies which take forms of strategic policy, regulation relaxation in business and health matters, financial aid people by governments are a positive steps but without people support and society awareness of scientifically health manner, those positive things might become futile. Therefore, people participation in health awareness and obedience in government rules not only vital in this current pandemic, but also become the front line to prevent the Covid-19 spread and hopefully if the full collaboration between society and government 
achieved, Indonesia would exit from the pandemic. Furthermore the President of Indonesia, Joko Widodo, had issued presidential instruction (Inpres) No. 06/2020 in order to force the people to obey the health protocol such as mask wearing, hand washing, social distancing and immunity boosting. The figure 3 illustrate the effect of the role from government and society to cope with the novel coronavirus. The faster the collaboration is achieved, the earlier the economy and health will be recovered.

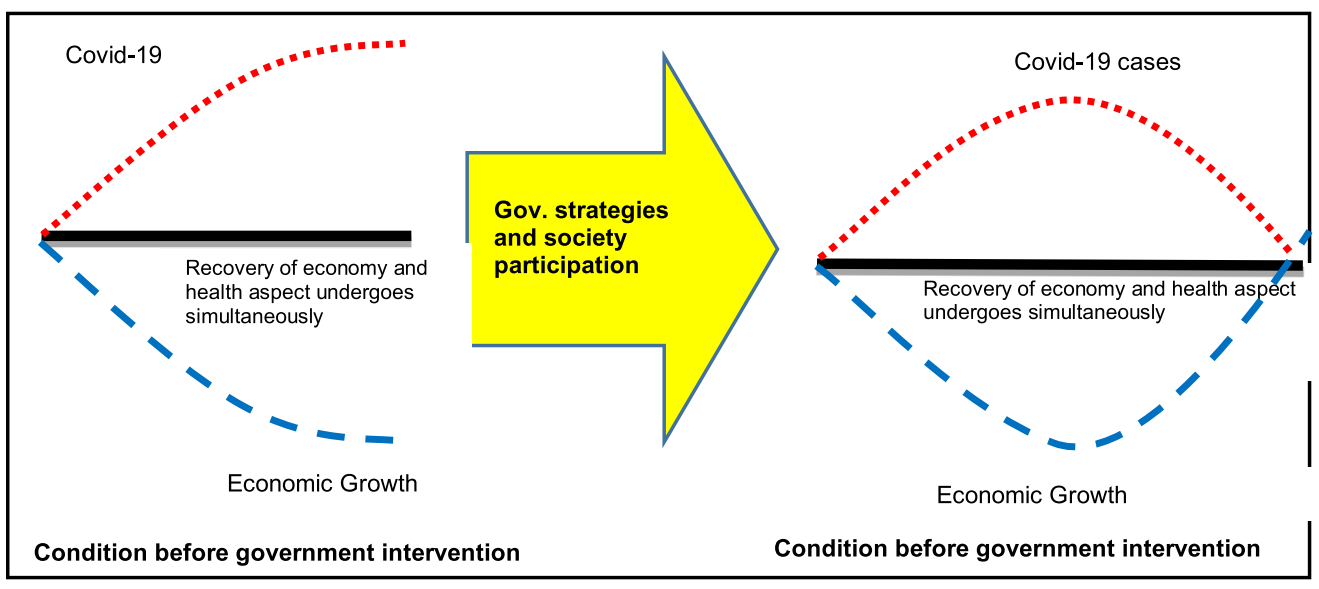

Fig. 3. Illustration of government and society involvement effect in recovery of health and economy aspects in Indonesia

Based on survey conducted in some countries regarding the 100 safest countries in the world for Covid-19 considering on indicator quarantine efficiency, monitoring detection, health readiness and government efficiency showed initially countries that could react quickly to crisis and had high levels of emergency preparedness ranked highest. On contrary, now countries with resilient economy are ranking higher which the first rank is Switzerland and the second rank is Germany. The careful ways which they are attempting to relax lockdown and economic freezing mandates in a fact and science-based manner help to stabilize the economy without sacrificing the public health aspects and safety $[16,17]$. Indonesian government by issuing the current regulation describes the steps taken is on the right track. Many challenges awaiting in health sector of Indonesia, yet the opportunities lies ahead are proven to be far greater.

\section{Conclusion}

The world currently has the sense of urgency and the same focuses towards how to overcome the Covid-19 pandemic which is still uncertain when the end will be. Governments and business society has established fast strategy and execution plan which considers the agility and resilience not only to the health issues but also the economy issues. People awareness to obey the health protocol act as the first line in coping with Covid-19 and defeat it as soon as possible.

The opportunity to obtain Covid-19 vaccine quickly has been taken by Indonesian government and also the private company by conducting transfer methods while develop Indonesian-owned vaccine simultaneously. Covid-19 rises up society's awareness towards Indonesia's biodiversity which could be developed to medicinal herbal to improve immune system as a key to avoid the virus pandemic. Covid-19 pandemic accelerates digital 
transformation in every aspects. It is time to focus on science development and innovation regarding the subjects which are virology, biomolecular and epidemiology comprehensively from upstream to downstream to prevent and to anticipate future diseases which might be caused by virus pandemic.

\section{References}

[1]. Covid-19 situation update worldwide. 2020, August 06. Retrieved from https://www.ecdc.europa.eu/

[2]. Hagemann, H. 2020, April 02. The 1918 flu pandemic was brutal, killing more than 50 million people worldwide. The coronavirus crisis. Retrieved from https://www.npr.org/

[3]. Soeriaatmadja, W. 2020, April 07. Indonesia ranks among world's worst in coronavirus testing rate. The jakarta post. Retrieved from https://www.thejakartapost.com/

[4]. Setiawan, B., Djohan S. (August 2016). Proses inovasi untuk peningkatan daya saing industri farmasi [power point slides]. Retrieved August 08, 2020, from https://www.drn.go.id/

[5]. Indonesa's annual inflation rate dropped to 1,54 percent in Juli 2020. 2020, August 01. Retrieved from https://www.tradingeconomics.com/

[6]. Abadi, D. (July 2020). Bekerja aman dan produktif di masa pandemi Covid-19 bagi industri farmasi [power point slides]. Retrieved July 15, 2020, from https://www.bit.ly/materihisfarinjateng/

[7]. IQVIA (July 2020). Monitoring the impact of Covid-19 on the pharmaceutical market [power point slides]. Retrieved Augustus 06, 2020, from https://www.iqvia.com/

[8]. World Health Organization (June 2020). Coronavirus disease 2019 (Covid-19) situation report - 11 [power point slides]. Retrieved August 06, 2020, from https://www.who.int/

[9]. Sutrisno, B. 2020, Juli 07. Sinovac collaboration could see COVID-19 vaccine ready by early 2021, Bio Farma claims. The jakarta post. Retrieved from https://www.thejakartapost.com/

[10].Rahman, R. 2020, April 22. Bio Farma to start pre-clinical trial for COVID-19 vaccine in 2021. The jakarta post. Retrieved from https://www.thejakartapost.com/

[11]. Syakriah, A. 2020, August 04. What you need to know about Indonesia's vaccine development. The jakarta post. Retrieved from https://www.thejakartapost.com

[12].Bostock, Bill. 2020, August 04. Russia says it will start mass-producing its coronavirus vaccine next month - as scientists say developers rushed through tests and injected themselves to shorten human trials. Business insider. Retrieved from https://www.businessinsider.com/

[13].Abidin, F. 2020, July 22. Saham farmasi cuan, IHSG tergelincir di akhir sesi II ke 5.110. Market watch. Retrieved from https://www.idxchannel.com/

[14].Lumanauw, N., Lona, O. 2020, Juli 21. Jokowi tasks Airlangga, Erick with fixing the economy and defeating Covid-19. Jakarta globe. Retrieved from https://www.jakartaglobe.id/

[15].Fachriansyah, R. 2020, July 21. Jokowi officially disbands 18 state bodies as govt shifts focus to pandemic mitigation. The jakarta post. Retrieved from https://www.thejakartapost.com/

[16].Koetsier, J. 2020, June 05. The 100 safest countries in the world for COVID-19. Innovation. Retrieved from https://www.forbes.com/

[17]. Boston Consulting Group (Juni 2020). Covid-19 BCG perspective [power point slides]. Retrieved Augustus 09, 2020, from https://www.media-publications.bcg.com/ 